\title{
Aksentuasi Sosial, Ekonomi, Budaya dan Agama Masyarakat Bugis Dalam Pengembangan Kualitas Hidup di Kabupaten Jembrana Bali
}

\author{
Accentuation in Social, Ekonomics, Culture and Religion of Bugis Society in \\ Developing The Quality of Life in Jembrana of Bali
}

\author{
Muhammad Habibi, I Wayan Subagiarta ${ }^{1}$, Fajar Wahyu Prianto \\ Jurusan Ekonomi Pembangunan, Fakultas Ekonomi dan Bisnis Universitas Jember \\ Jln. Kalimantan 37, Jember 68121 \\ Email : wayansubagiarta@rocketmail.com
}

\begin{abstract}
Abstrak
Kualitas hidup saat ini merupakan isu prioritas bagi banyak negara dan kualitas hidup saat ini telah digunakan secara umum untuk menggambarkan kesejahteraan individual dalam suatu masyarakat. Penelitian ini bertujuan agar mengetahui bagaimana karakteristik dan peran masyarakat bugis terhadap kualitas hidunya di Kabupaten Jembrana yang terkait dengan aspek Sosial , Ekonomi, Budaya dan Agama. Metode Analisis yang di gunakan dalam penenilian ini adalah Analisis Participatori Rural Appraisal (PRA) dan Metode Depth Interview. Dari hasil analisis tersebut disimpulkan bahwa Masyarakat Bugis Loloan banyak mengalami perubahan-perubahan, perubahan yang terjadi mulai dari nilai Sosial, Ekonomi, Budaya dan Agama.
\end{abstract}

Kata kunci: Kualitas hidup manusia, sosial, ekonomi, budaya, agama.

\section{Abstract}

Nowadays the quality of life as the priority issue for many countries and the quality of human's life in generally has been used to describe individual prosperous in society. This research purposes to find out the characteristic and the role of Bugis society towords their quality of life in Jembrana regency which is connected to social, economics, culture and religion aspect. The analysis method which is used in this research is Participatori Rural Appraisal (PRA) method and Depth Interview method. From those result of analysis can be concluded that Loloan Bugis society has some changes. The changes happen to the social, economics, culture and religion value.

Keywords : The quality of human's life, Social, Economics, Culture, Religion

\section{Pendahuluan}

Salah satu tujuan dari pembangunan Indonesia adalah pembangunan sumber daya manusia. Banyak kemajuan yang sudah dicapai, namun dengan dinamika perubahan global, kualitas manusia Indonesia masih harus mengejar ketertinggalannya dari banyak negara di kawasan regional maupun internasional.

Kualitas hidup saat ini merupakan isu prioritas bagi banyak negara dan kualitas hidup saat ini telah digunakan secara umum untuk menggambarkan kesejahteraan individual dalam suatu masyarakat. Kualitas hidup menjadi variabel perkembangan masyarakat yang terpenting dan dianggap sebagai faktor yang dapat menstimulasi perkembangan suatu masyarakat (Molnar dalam Nofitri, 2009).

Namun selama ini masih dirasakan bahwa potensi sumber daya manusia tersebut belum dapat dimanfaatkan secara optimal, mengingat sebagian besar dari angkatan kerja tingkat keterampilan dan pendidikannya masih rendah. Keadaan tersebut masih besar pengaruhnya terhadap sikap mental

\section{Coresponding Author}

tenaga kerja dilingkungan kerjanya yang berakibat rendahnya hasil kerjanya. Hal ini berakibat pada rendahnya tingkat pendapatan dan kesejahteraannya (Sinungan, 2005:133). Pemberdayaan sumberdaya manusia adalah usaha untuk memperbesar kemampuan berproduksi seseorang atau masyarakat, baik dalam pekerjaan dan lain-lain kegiatan yang dapat memperbaiki taraf hidup bagi diri sendiri atau orang lain (Suroto, 2000:15).

Pengembangan sumber daya manusia diperlukan dalam menciptaan suatu sumber daya manusia yang produktif. Untuk itu perlu dilakukannya usaha-usaha peningkatan kualitas sumber daya manusia, seperti dengan diadakannya pelatihan, peningkatan kualitas pendidikan, dan lain sebagainya. Proses pendidikan pada hakekatnya merupakan suatu proses pemberdayaan, yaitu suatu proses untuk mengungkapkan potensi yang ada pada manusia sebagai individu yang selanjutnya dapat memberikan sumbangan kepada keberdayaan masyarakat lokal, kepada masyarakat bangsanya, dan pada akhirnya kepada masyarakat global (Tilaar, 1997:132). produktivitas itu sendiri harus di dukung oleh tingkat investasi dan sumberdaya manusia yang 
memadai (Simanjuntak, 2001:23).

Kualitas hidup saat ini merupakan isu prioritas bagi banyak negara dan kualitas hidup saat ini telah digunakan secara umum untuk menggambarkan kesejahteraan individual dalam suatu masyarakat. Kualitas hidup menjadi variabel perkembangan masyarakat yang terpenting dan dianggap sebagai faktor yang dapat menstimulasi perkembangan suatu masyarakat (Molnar dalam Nofitri, 2009).

Permasalahan pembangunan yang seringkali muncul diantaranya masalah ketidakmerataan kesejahteraan, baik antar individu, antar komunitas, maupun antar tempat. Kesenjangan kesejahteraan antar individu mendorong permasalahan kemiskinan dan kriminalitas. Kesenjangan kesejahteraan antar komunitas mendorong permasalahan segregasi sosial dan konflik masyarakat. Kesenjangan antar tempat mendorong ketimpangan struktural yang lebih luas. Secara umum, ketimpangan yang terjadi di masyarakat akan mendorong merosotnya kualitas hidup masyarakat.

Sebagai komunitas minoritas, masyarakat Bugis di Kabupaten Jembrana tidak banyak menguasai sektor ekonomi utama. Secara teoritis, penguasaan sektor-sektor ekonomi utama dapat berpotensi memicu besarnya sentimen etnis, dan adanya prejudice membuat konflik meranah aspek sosiologis lainnya. Persaingan hidup antar etnis ini dapat mendorong kecemburuan sosial antara etnis pendatang (suku Bugis) dengan etnis asli (Hindu) yang mendiami Pulau Bali. Meskipun demikian, hingga saat ini belum ada permasalahan mencolok terkait dengan ketimpangan kesejahteraan yang terjadi.

\section{Metode}

Penelitian tentang aksentuasi sosial, ekonomi, budaya, dan agama masyarakat Bugis dalam pengembangan kualitas hidup di Kabupaten Jembrana Bali ini merupakan penelitian eksploratif (exploratory research). Pendekatan yang digunakan dalam penelitian ini adalah pedakatan kualitatif. Unit analisis dalam penelitian ini adalah orang-orang Bugis, dengan masyarakat Bugis yang tinggal di Kabupaten Jembrana Bali sebagai populasinya. Oleh karena pertimbangan itu, Sampel adalah sebagian Jumlah dan karakteristik yang dimiliki oleh populasi tersebut (Sugiyono, 2003:116). sampel penelitian adalah masyarakat Bugis di Kelurahan Loloan Timur dan Kelurahan Loloan Barat sebagai komunitas Bugis terbesar di Kabupaten Jembrana. Key informan merupakan tokoh masyarakat di wilayah tersebut yang memahami betul tentang budaya dan perilaku sosial ekonomi orang Bugis terkait dengan upaya peningkatan kualitas hidup.

Penelitian ini menggunakan data primer sebagai sumber informasi utama. Data primer merupakan data yang diperoleh dan digali dari sumber utamanya (sumber asli) berupa data kualitatif (Teguh, 2005:122) dan data sekunder sebagai data pendukung.

Penelitian aksentuasi budaya masyarakat bugis ini, berdasarkan fokus dan tujuan penelitian, menggunakan 2 (dua) alat analisis, yaitu: (i) Metode Participatory Rural Appraisal (PRA) yaitu metode interaksi dengan masyarakat desa, mencoba untuk mengerti tentang keadaan masyarakat tersebut dan belajar dari mereka ( Chambers dalam
Permanasari, 2011), untuk tujuan mengetahui karakteristik masyarakat, (ii) Metode Depth Interview adalah proses memperoleh keterangan untuk tujuan penelitian dengan cara tanya jawab sambil bertatap muka antara pewawancara dengan responden atau orang yang diwawancarai, dengan atau tanpa menggunakan pedoman (guide) wawancara dimana pewawancara dan informan terlibat dalam kehidupan sosial yang relatif lama (Sutopo 2006:72).

\section{Hasil dan Pembahasan}

\section{Karakteristik Masyarakat Bugis dalam Pengembangan Kualitas Hidup di Kabupaten Jembrana Bali}

Sebelum merdeka dan setelah merdakah ada beberapa perubahan yang terjadi pada kehidupan masyarakat bugis yang berada di Jembrana khususnya pada Kelurahan Loloan barat dan Kelurahan Loloan Timur. Perubahan yang terjadi ini meliputi nilai Sosial, Ekonomi, Budaya dan Agama.

\section{A. Nilai Sosial}

Menurut hasil wawancari dari salah satu tokoh masyarakat Loloan H. Musadat (06-10-2015) perubahan yang terjadi dari nilai sosial sebagai berikut : "Ikatan Silaturrahmi mulai berkurang, zaman dahulu masyarakat Bugis Muslim Loloan dan masyarakat Hindu saling berkunjung kerumah ketika hari Raya besar, akan tetapi setelah perkembangan zaman kebiasaan itu mulai ditinggalkan oleh masyarakat Muslim dan masyarakat Hindu yang ada di Loloan. Saat ini masih ada tetapi hanya segelintir orang saja dan hanya ikatan silaturrahmi yang tetap berjalan di Loloan antar sesama Muslim dari dulu hingga sekarang tetap terjalin”.

Menurut hasil wawancari dari seorang Budayawan/ tokoh masyarakat Loloan H. Ahmad Damanhuri (15-10-2015) perubahan yang terjadi dari nilai sosial sebagai berikut : "Orang bugis dahulu suka menyantuni anak yatim dan sampai saat ini masih tetap terjadi, banyak orang-orang bugis pada saat ini yang mulai sadar akan bersedekah atau beramal dan cara menyantuninyapun bermacam-macam, diantaranya dengan cara memberikan uang, bingkisan, sembako, pakaian dan lain-lain".

\section{B. Nilai Ekonomi}

Pada masa sebelum kemerdekaan profesi masyarakat Loloan sebagai Nelayan dan Pedagang, ini tebukti dengan orangorang Bugis tekenalnya sebagai seorang pelaut, sesuai dengan hasil wawancara dengan salah satu tokoh masyarakat loloan H. Musadat (06-10-2015) mengatakan bahwa "orang-orang Bugis ketika masuk di Kabupaten Jembrana ini dengan menggunakan perahu jenis Lambao, perahu jenis Lambau ini yang digunakan oleh masyarakat Bugis untuk mencari ikan di laut dan berdagang". Pendapat ini diperkuat dengan hasil wawancara dengan H. Shodikin (20-11-2015) mengatakan "masyarakat Bugis menjadi nelayan sudah pada waktu zaman dahulu dan dahulu masyarakat Bugis menggunakan jala sebagai alat tangkap ikan dilaut dengan perkembangan zaman yang semakin modern, masyarakat Bugis sangat ini menggunakan jaring atau kolor yang berdiameter besar sebagai alat tangkap ikan dan menggunakan banyak tenaga nelayan, sekitar 50 nelayan dalam satu perahu".

Dari segi pedagang di Loloan untuk saat ini pedagang di Loloan sudah banyak sekali menurut hasil wawancara dari 
Ahmad Fauzan (21-11-2015) salah satu pedagang di Loloan mengatakan " pedagang dahulu tidak banyak memiliki saingan, sedangakan saat ini pedagang mulai memiliki banyak saingan dan produk yang di jual juga semakin beragam". Minat akan berbelanja masyarakat Bugis yang ada di Loloan ini tergantung dari hasil pendapatan menangkap ikan, semakin banyak hasil tangkapan ikan yang diperoleh maka semakin tinggi tingkat konsumsi masyarakat Loloan begitupula sebaliknya.

\section{Nilai Budaya}

Perubahan Budaya yang terjadi menurut hasil wawancara dengan salah satu tokoh masyarakat H. Fathurrahim (18-102015) mengatakan "Terjadi akulturasi atau percampuran, dilihat dari orang Bugis dahulu kalau melakukan upacara pernikan, perayaannya itu sampai tujuh hari tujuh malam, tetapi tidak untuk saat ini perayaan pernikahan itu lebih efisien mencadi dua hari".

Dari segi pakaian, menurut hasil wawancara dari budayawan Loloan H. Ahmad Damanhuri (15-10-2015) "Dahulu masyarakat Bugis cara berpakaiannya menggunkan kain kamben dan udeng khas Bugis, seiring dengan pekemkembanganya kebisaan cara berpakaian itu mulai hilang, dikarenakan banyak orang-orang Bugis Loloan pada saat ini yang sudah berpendidikan". Dengan berpendidikan seakan-akan pola pikir masyarakat Bugis Loloan ini mulai modern dan kebiasaan perpakainnya mulai hilang.

Menurut hasil wawancara dengan H. Ahmad Damanhuri (1510-2015) mengatakan "pada zaman dahulu rumah-rumah masyarakat Bugis di Loloan menggunakan kayu berupa rumah panggung, tetapi dengan berkembangnya zaman seperti sekarang ini banyak rumah-rumah panggung yang sudah dirobohkan oleh pemiliknya dan diganti dengan rumah modern seperti sekarang”.

\section{Nilai Agama}

Kesadaran akan agama semakin bertambah pada masyarakat Bugis di Loloan. Hasil wawancara dengan tokoh masyarakat Loloan H. Fathurrahim yang saat ini memiliki Pondok Pesantren Nurul Ikhlas mengatakan "kesadaran Agama terlihat dari banyaknya banyaknya Masyarakat Loloan yang berangkat Haji, banyaknya orang tua yang menyuruh anaknya untuk belajar mengaji di Guru-guru ngaji (ahli Agama) dan banyak Masyarakat Loloan yang mondok di Pesantrenpesantren untuk memperdalam ilmu Agamanya".

\section{Aspek Sosial, Ekonomi, Budaya dan Agama Masyarakat Bugis di Kabupaten Jembrana}

Masyarakat Jembrana khususnya yang berada di Loloan memiliki beberapa peranan yang penting dalam pengembangan hidupnya, banyak di antara orang-orang Bugis ini yang menjadikan Jembrana semakin berkembang. Beberapa aspek peranan masyarakat Bugis di Jembrana :

\section{A. Aspek Sosial}

Menurut hasil wawancara tokoh mayrakat Loloan $\mathrm{H}$. Musadad (06-10-2015) mengatakan "ada tanggung jawab sosial yang harus di jaga pada masyarakat Loloan, seperti kewajiban-kewajiban bersama, misalnya melakukan sholat berjama'ah di Masjid, melakukan upacara adat dan gotong royong". Ini merupakan suatu kesadaran yang harus dimiliki oleh masyarakat yang ada di Loloan.

Hasil wanwancara seorang tokoh masyarakat Loloan $\mathrm{H}$. Ahmad Damanhuri (15-10-2015) mengatakan " kebiasaan orang Bugis untuk bersosial tinggi, dilihat dari kebiasaan orang Bugis beramal dan sistem kekerabatan yang masih tetap terjalin".

Jadi, kebiasaan-kebiasaan orang Muslim Bugis yang ada di Loloan Kanbupaten Jembrana ini memiliki sikap saling berkaitan antar satu dengan yang lainnya. Seperti ketika melakukan kegiatan-kegiatan mereka cenderung bersamasama dan saling peduli. Hal ini sesuai dengan teori kebutuhan Maslow yang ketiga: kebutuhan sosial (affiliation or acceptance needs) yaitu kebutuhan yang berkaitan dengan sosial, teman, interaksi, dicintai dan mencintai serta diterima dalam pergaulan kelompok pekerja dan lingkungan.

\section{B. Aspek Ekonomi}

Menurut hasil wawancara dari salah seorang tokoh masyarakat Loloan H. Fathurrahim (18-10-2015) mengatakan "yang mengalir di darah Bugis (masyrakat Loloan) ini adalah darah perantau, maka semangat untuk berekonomi lebih tinggi ketimbang orang lokal". Karna kehidupan orang-orang Bugis ini berada di pesisir, Sumber pendapatan masyarakat Loloan berasal dari laut, maka pekerjaan mereka menjadi nelayan. Selain menjadi nelayan banyak juga orang Bugis yang bekerja menjadi pedagang.

Menurut hasil wawancara dari salah satu nelayan di Loloan H. Shodikin (20-11-2015) mengatakan "sistem penangkapan ikan sudah modern, menggunakan jaring/kolor dan mesin sebagai alat tangkapnya dan besar perahu yang di gunakan berukuran panjang 12,5 meter dan lebar 5 meter.

Dari segi pedagang yang ada di Loloan menurut hasil wawancara dari salah satu pedagang Ahmad Fauzan (21-112015) mengatakan "untuk pedagang saat ini dirasa mulai mengalami kesulitan dari segi pemasaran dengan pedagang yang semakin banyak, dari segi harga yang bersaing dan keterbatasan modal yang dimiliki, semakin banyak pengambilan barang dari agen maka pedang akan mendapatkan harga yang semakin murah".

Dengan adanya perkembangan seperti itu maka tingkat pendapatan atau kesejahteraan masyarakat lebih meningkat ketimbang dahulu ini terlihat dengan banyaknya bangunanbangunan permanen yang ada di Loloan. Hal ini sesuai dengan teori Sukirno yang menunjukkan nilai pendapatan perkapita sebagai indeks untuk menunjukkan perbandingan tingkat kesejahteraan. Disamping tingkat pendapatan, distribusi pendapatan merupakan faktor penting lainnya yang menentukan keadaan kesejahteraan masyarakat pada umumnya.

\section{Aspek Budaya}

Menurut hasil wawancara dari H. Ahmad Damanhuri (15-102015) mengatakan bahwa " budaya yang masih tetap dilestarikan dan dipertahankan yaitu berupa seni budaya Rebane dan Pencak Silat".

Rebane ini sejenis gendang besar dan Para pemain dari seni budaya rebana ini dimainkan oleh orang laki-laki saja. Seni budaya ini biasannya dimainkan pada saat salah seorang istri masyarakat Loloan yang sedang hamil tua atau menyambut 
kelahiran bayi dan ketika upacara Nelai atau potong rambut (upacara pemberian nama pada bayi). Seni budaya Pencak Silat Bugis ini menggambarkan pasukan-pasukan masyarakat Bugis pada masa kerajaan yang sangat terkenal ketangguhannya, agar generasi pemuda-pemuda yang ada di Loloan dapat menjadikan contoh dan memupuk rasa saling menghargai tanpa memandang perbedaan.

Dari segi bahasa, menurut hasil wawancara dari tokoh masyarakat H. Musadat (06-10-2015) mengatakan "Masyarakat Bugis Loloan pada saat ini tidak menggunakan Bahasa Bugis sebagai Bahasa sehari-hari, tetapi menggunakan Bahasa Melayu sebagai Bahasa sehari-hari mereka.

\section{Aspek Agama}

Mayoritas penduduk Loloan berasal dari Bugis maka kebanyakan dari meraka beragama Islam. Keberadaan Islam di Kabupaten Jembrana ini khususnya di Loloan sudah menjadi turun-temurun, masyarakat Loloan masih tetap memegang teguh Agama Islam yang dibawa oleh leluhurnya. Berdasarkan hasil wawancara dari H. Fathurrahim (18-102015) mengenai upacara-upacara Agama yang terkait dengan kehidupan pada masyarakat Loloan yaitu : (1) upacara pada saat bayi masih dalam kandungan berumur tujuh bulan disebut nujuh bulani. (2) upacara kelahiran atau pemberian nama pada bayi disebut nelai. (3) upacara Khitan disebut mesunat.(4) upacara ketika hatam membaca Al Qur'an pada anak disebut Hataman. (5) upacara pada anak ketika memasuki dewasa disebut Naek Terune. (6) upacara pernikahan disebut mekawen. (7) upacara kematian disebut mejenukan.

\section{Simpulan}

Berdasarkan hasil pembahasan dalam penelitian ini maka dapat disimpulkan sebagai berikut:

1. Karakteristik Masyarakat Bugis Di Kabupaten Jembrana Bali, banyak terjadi perubahan-perubahan di masyarakat Bugis yang ada di Loloan pada saat sebelum dan setelah merdeka.

\section{a. Nilai Sosial}

Kesadaran masyarakat Muslim Loloan akan bersosial mengalami perubaha-perubahan. Ikatan silaturrahmi antar umat Islam dan Hindu di Loloan sudah mengalami penurunan, namun ikatan silaturrahmi antar sesama Muslim Loloan tetap terjalanin sampai sekarang, cara menyantuni anak yatim yang beragam, melaksanakan Khitan masal.

\section{a. Nilai Ekonomi}

Terjadinya perubahan dengan sistem peralatan untuk mencari ikan di laut yang lebih modern, sehingga pendapatan mereka semakin bertambah. Dan pedagang di Loloan saat ini mengalami persaingan dengan pedagangpedagang lainnya, berbeda pada saat dahulu pedagang masih sedikit.

b. Nilai Budaya

Karna terjadi akulturasi Budaya banyak kebiasaankebiasaan Masyarakat Loloan yang mulai berubah seperti ketika waktu upacara pernikahan mulai lebih efesien, dari pakaian yang sudah modern dan rumah yang sudah modern juga.

c. Nilai Agama

Kesadaran akan Agama semakin bertambah, terlihat dari banyaknya Masyrakat Loloan yang berhaji, mengajikan anaknya dan banyak Masyarakat Loloan yang mondok di Pesantren-pesantren.

2. Aspek sosial, ekonomi, budaya dan agama dalam pengembangan kualitas hidup masyarakat bugis di kabupaten jembrana.

a. Aspek Sosial

Masyarakat Loloan memiliki tanggung jawab kebersamaan dalam kehidupannya, dengan melakukan sholat jama'ah di Masjid, upacara-upacara adat dan gotong royong, ini dilakukan atas dasar kesadaran masyarakat sendiri.

b. Aspek Ekonomi

Banyak dari Masyarakat Bugis Loloan yang berprofesi sebagai nelayan dan pedagang sebagai matapencahariannya. Masyarakat Bugis mulai mengalami persaingan dalam berdagang, ini terlihat dari banyaknya pedagang yang ada saat ini.

c. Aspek Budaya

Budaya yang masih dipertahankan di Loloan adalah seni Budaya Rebane dan seni Budaya Pencak Silat, ini biasa dipertunjukkan ketika hari-hari besar ada ketika sedang ada upacara agama. Budaya dalam menggunakan Bahasa melayu sebagai bahasa sehari-hari.

d. Aspek Agama

Masyarakat Loloan yang masih tetap mempertahankan Agama Islam yang dibawa oleh leluhurnya dan tetap melestarikan upacara-upacara Agama yang sudah ada.

\section{Referensi}

Nofitri, N F M. 2009. Gambaran Kualitas Hidup Penduduk Dewasa di Jakarta. Dipublikasikan. Skripsi: Universitas Indonesia.

Tilaar, H.A. R. 1997. Pengembangan Sumber Daya Manusia Dalam Era Globalisasi. Jakarta: Gramedia.

Teguh, Muhammad. 2005. Metodologi Penelitian Ekonomi Teori dan Aplikasi. Jakarta: PT Raja Grafindo Persada.

Permanasari, Ika Kusuma. 2011. Pemberdayaan Masyarakat melalui Desa Wisata dalam Usaha Peningkatan Kesejahteraan (Desa Candirejo, Magelang, Jawa Tengah). Dipublikasikan. Tesis. Jakarta: FE-UI.

Simanjuntak, P.J. 2001. Pengantar Ekonomi Sumber Daya Manusia. Jakarta: LPFE UI.

Sinungan, M. 2005.Produktivitas Apa dan Bagaimana. Jakarta : Bumi Putera.

Sugiyono. 2009. Metodologi Penelitian untuk Bisnis. Jakarta: Salemba Empat.

Suroto. 2000. Strategi Pembangaunan dan Perencanaan Kesempatan Kerja. Yogyakarta: Gajah Mada Univercity.

Sutopo. 2006. Metodologi Penelitian Kualitatif. Surakarta: UNS 